\title{
Celiac disease presenting with extraintestinal manifestations
}

\author{
Barsak dışı belirtiler ile başvuran Çöliak hastası \\ Şule Bilen ${ }^{1}$, Memet Aslanyavrusu ${ }^{1}$, Aylin Bolat ${ }^{2}$, Fikri Ak ${ }^{1}$ \\ ${ }^{1}$ Second Neurology Clinic of Ankara Numune Trainig and Research Hospital \\ ${ }^{2}$ Gastroenterology Department of Ankara Atatürk Training and Research Hospital
}

\begin{abstract}
Celiac disease (CD) is a multiorgan involved systemic disease that most commonly affects the gut but also affects other organs. Up to $10 \%$ of patients with CD and gastrointestinal symptoms have otherwise unexplained neurological presentations. In this paper we report a case with the final diagnosis of celiac disease while being investigated for the underlying etiology of iron deficient anemia, peripheral neuropathy, and gait and speech disturbances. $J$ Clin Exp Invest 2010; 1(3): 211-213
\end{abstract}

Key words: Celiac disease, gluten sensitivity, speech disturbance, peripheral neuropathy, gait disturbance.

\section{INTRODUCTION}

Celiac disease (CD) is an autoimmune disease of small intestine precipated by the ingestion of gluten in genetically susceptible individuals. ${ }^{1}$ The risk of having celiac disease is much higher in certain groups such as the ones who have first degree relatives with $\mathrm{CD}$, the patients with the diagnosis of type 1 diabetes, autoimmune thyroid and liver disease, Down's syndrome, Turner's syndrome and Williams syndrome. ${ }^{2}$

The symptoms of the disease may appear in infancy by ingestion of cereals or may first appear in adulthood. Classic signs are related to the gastrointestinal tract. ${ }^{1}$ Major advances in the understanding of this disease have expanded it from a gastrointestinal disease to multisystem immunological disorder. $^{2}$

Extraintestinal manifestations include anemia, coagulopathy, metabolic bone diseases, infertility, psychiatric syndromes and various neurological disorders ${ }^{1}$. Neurologic complications occur in approxi-

\section{ÖZET}

Çölyak hastalığı çoklu organ tutulumu gösteren, sıklıkla barsakları etkilemekle birlikte, diğer organları da etkileyebilen bir hastalıktır. Mide-barsak semptomları olan Çölyak hastalarının \%10 kadarında açıklanamayan nörolojik belirtiler bulunur. Bu yazıda demir eksikliği anemisi, periferik nöropati, ve yürüme ve konuşma bozuklukları için araştırılırken sonuç olarak Çölyak hastalığı tanısı alan bir olgu sunulmaktadır. Klin Den Ar Derg 2010; 1(3): 211-213

Anahtar kelimeler: Çölyak hastalığı, gluten duyarlılı̆ı, konuşma bozukluğu, periferik nöropati, yürüme bozukluğu

mately $8 \%$ to $10 \%$ of adults with CD. These include epilepsy, associated particularly with occipital calcifications and folate deficiency, cerebellar ataxia, peripheral neuropathy, myositis, neuromyotonia, myasthenic syndrome, myelopathy, and dementia accompanied by brain atrophy in adults. ${ }^{3}$ In this paper we report an adult patient who did not have any intestinal symptoms of CD but presented with various neurological manifestations of the disease.

\section{CASE}

A 21 year old female presented to our outpatient clinic suffering from gait and speech disturbances which detorriated during the last few years. Also her mother complained of her apathy and clumsiness of her hands. She did not report any health problem until the age 17. Later then she has begun to walk by wide steps which deterriorated by time and fluency of her speech has been slowed. She has not been interested in most of the activities such as reading, knitting, cleaning and going around that she was used to do before. Her physical examination revealed hir- 
sutism and bilateral toe abnormality accompanying to pes cavus (which were also reported as occurring in last few years). In neurological examination she had mild ataxic gait and slowed speech, depressive mood and apathic looking face. She did not have motor or sensorial impairment. Her deep tendon reflexes were normal in upper and brisk in lower extremities. She did not have dysmetria or dysdiadocokinesia. In routine blood test iron deficiency was found. Neurophysiological assessment was relevant with mild, demyelinating type peripheric polyneuropathy. Cerebral white matter lesion was observed on cranial magnetic resonance imaging (Figure 1).

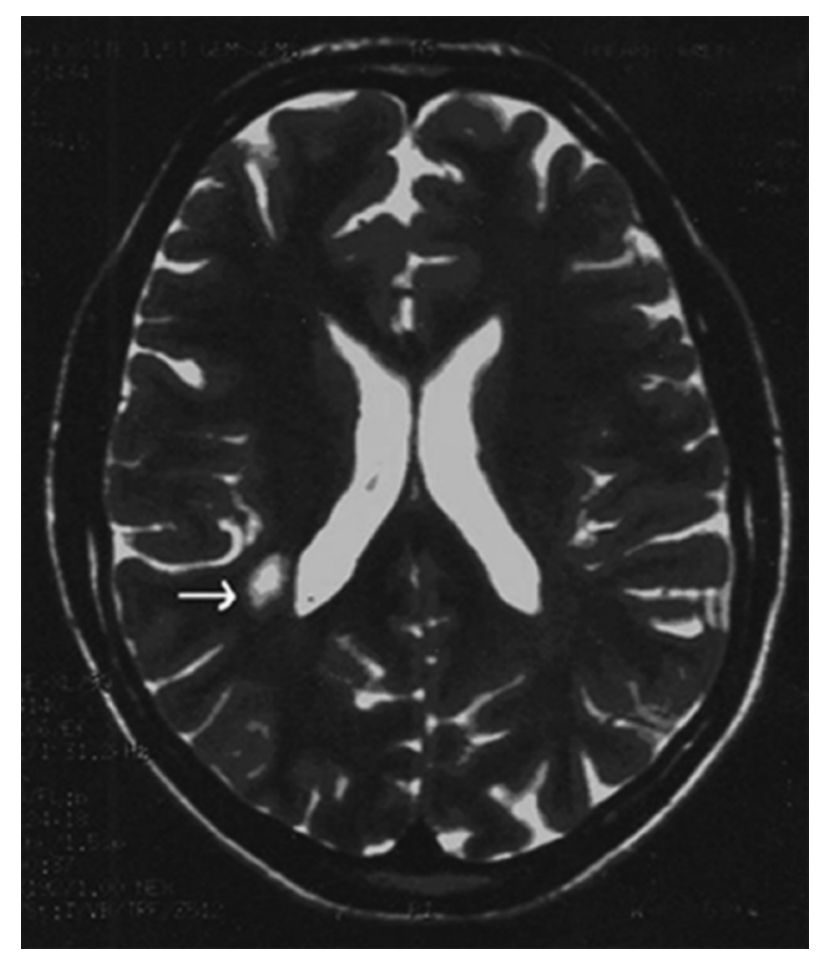

Figure 1. T2 weighted image of a hyperintense lesion located near the lateral ventricule.

The lesion was hyperintense on T2 weighted images and hypointense on T1 weighted images suggesting ischemia. For the etiology of this lesion tests for vasculitis (such as anti-dsDNA, ANA, anticardiolipin antibodies etc) and multiple sclerosis (such as oligoclonal band in cerebrospinal fluid, evoked potentials etc) were performed. But the results did not reveal the suspected diseases. Her cervical and thoracal magnetic resonance images were also normal. Since she had ataxia and since laboratory investigations revealed iron deficiency and mild, demyelinating type peripheral motor neuropathy she was assessed for the composition of these findings and gluten ataxia had been suspected. Then she was investigated for serum antigliadin antibodies. Serum antigliadin Ig A level was $87 \mathrm{RU} /$ $\mathrm{ml}$ (normal levels were 0.0-50.0 RU/ml), antigliadin IgG, antiendomysium IgA antibodies, antitissuetransglutaminase $\operatorname{IgG}$ and $\operatorname{IgA}$ were negative. Since antigliadin IgA level had been found high other malabsorptional situations which could be accompanying to gluten ataxia such as vitamin $\mathrm{D}, \mathrm{E}$, B12 and folic acid deficiencies were investigated. Minimal vitamin D3 deficiency (25-0H- vitamin D3 level was $19.5 \mathrm{ug} / \mathrm{L}$; reference levels of the laboratory were $20-120 \mathrm{ug} / \mathrm{L}$ ) was present where as the others (vitamin E, B12, folic acid levels) were in normal levels. Bone mineral dansitometry findings were compatible with osteopenia that could be seen in celiac disease.

Serum levels of $\mathrm{IgG}$ was $5.6 \mathrm{~g} / \mathrm{L}$ (Normal: 7.00-16.00), and serum levels of IgA was $0,56 \mathrm{~g} / \mathrm{L}$ which was lower than the laboratory reference levels (Normal:0.70-4.00 g/L). After the prediagnosis of gluten ataxia had been supported genetical test for the celiac disease was made. She was carrying HLA-DQ2(A1*0501, B1*0201) heterodimer. Mini mental status test was performed to explain if her apathy was because of cognitive impairment but the score was 30 (normal).

After all noninvasive laboratory investigations pointing to celiac disease and gluten ataxia, she had been consulted by a specialist of gastroenterology and according to her advise duodenal biopsy was performed and lymphocyte infiltration was reported in biopsy materials. When the patient's history, physical, neurological examination and laboratory findings had been taken account she was diagnosed definitely as celiac disease without the classical intestinal symptoms. Gluten free diet and iron replacement treatment were initiated and for her depressive mood sertralin $50 \mathrm{mg}$ per day and risperidone $1 \mathrm{mg}$ per day were administered. Three months later, antigliadin IgA level was measured again and it was 18.9 U/ml (Normal: 0-12 U/mL). Seven months later control electroneurography was performed and it was almost normal. She did not have iron deficiency at the control examination. She was more alert, her hand functions and gait were minimally improved. 


\section{DISCUSSION}

Celiac disease is a $\mathrm{T}$ cell-mediated inflammatory disorder with autoimmune features and has enviromental and immunologic components. Whereas classical CD refers to manifestations with diarrhea and malabsorption syndrome, atypical form has no gastrointestinal presentations ${ }^{4}$. It may present with various neurological manifestations even without clinical evident of malabsorption of nutricients. Although neurological symptoms are rare in children, as many as 36 percent of adult patients have been reported to have neurological presentations. ${ }^{1}$

Our patient suffered from atypical clinical manifestations such as depressive mood, cerebellar symptoms, clumsiness of hands, neuropathy, osteopenia and anemia, but she had none of the classical intestinal symptoms. This clinical picture demonstrated that neurological and psychiatric signs may be the diagnostic manifestations of $\mathrm{CD}$. We found some other papers reporting neurological and psychiatric symptoms as the first or the only clinical presentation of the disease..$^{1,35}$

CD is strongly associated with HLA class II genes that map to the expression of HLA-DQ2 and HLA-DQ8. Several studies found that majority of celiac patients carry DQ2(DQA1*/DQB1*02) and so did our patient ${ }^{4}$. Focal white matter lesions in the brain may represent an extraintestinal involvement of CD. They may be ischemic in origin as a result of vasculitis or caused by inflammatory demyelination $^{3}$. The patient also had a periventricular white matter lesion which is an extremely rare finding in CD.

Gastrointestinal involvement in $\mathrm{CD}$ may produce malabsorption and some of the neurologic manifestations of the disease may be related to vitamin deficiencies but she did not have B12, folate and vitamin E deficiencies, she only had iron deficient anemia and osteopenia which could be related to mild vitamin D insufficiency. Cognitive impairment associated to CD can sometimes be the initial clinical manifestation of the disease. ${ }^{6}$ However, we did not establish cognitive impairment but she was apathic and had clumsiness of hands. She showed some improvement in this clinical picture after seven months of gluten free diet.
Pathphysiology of cognitive and psychiatric disturbances in patients with CD remains to be determined. An immunologic etiology cannot be ruled out. Antigliadin antibodies have been found in the cerebrospinal fluid in patients with gluten sensitivity and neurological dysfunction. Nevertheless these antibodies are present in almost all patients with CD but, only a small proportion of them develop neurological symptoms. One hypothesis may be that antigliadin antibodies only become neurotoxic if they can invade to the central nervous system ${ }^{1}$. Our patient's having high levels of antigliadin IgA levels but low serum levels of IgG and IgA made us consider about an underlying pathogenic immunity.

In conclusion, celiac disease is not only the disease of intestine but also the disease of other systems. Although neurological manifestations in patients with established celiac disease have been reported since 1966, it was not until 30 years later that, in some individuals, gluten sensitivity was shown to manifest solely with neurological dysfunction. Furthermore, the concept of extraintestinal presentations without enteropathy has only recently become accepted. ${ }^{7}$ For this reason; CD must be considered whenever a neurologist comes across to neurological manifestations of unexplained origin.

\section{REFERENCES}

1. Siqueira Neto JI, Costa AC, Magalhães FG, Silva GS. Neurological manifestations of celiac disease. Arq Neuropsiquiatr 2004;62:969-72.

2. Ravikumara M, Tuthill DP, Jenkins HR. The changing clinical presentation of coeliac disease. Arch Dis Child 2006;91:969-71.

3. Kieslich M, Errázuriz G, Posselt HG, Hartman WM, Zanella F, Boehles H. Brain white-matter lesions in celiac disease: A prospective study of 75 diet-treated patients. Pediatrics 2001;108; 21 .

4. Torres MI, Casado MAL, Ríos A. New aspects in celiac disease. World J Gastroenterology 2007;13:1156-61.

5. Ihara M, Makino F, Sawada H, et al. Gluten sensitivity in Japanese patients with adult-onset cerebellar ataxia. Internal Medicine 2006;45:135-40.

6. Hu WT, Murray JA, Greenaway MC, Parisi JE, Josephs KA. Cognitive impairment and celiac disease. Arch Neurol 2006;63:1440-6.

7. Hadjivassiliou M, Sanders DS, Grünewald RA, Woodroofe N, Boscolo S, Aeschlimann D. Gluten sensitivity: from gut to brain. Lancet Neurol 2010;9:318-30. 